\title{
Iron-deficiency anemia and associated
} factors among preschool children in Diamantina, Minas Gerais, Brazil

\author{
Anemia ferropriva entre pré-escolares \\ do município de Diamantina, Minas \\ Gerais e fatores associados
}

Luciana Neri NOBRE ${ }^{1}$

Angelina do Carmo LESSA ${ }^{1}$

Hilda Christiane de OLIVEIRA ${ }^{1}$

Joel Alves LAMOUNIER ${ }^{2}$

Sylvia do Carmo Castro FRANCISCHINI ${ }^{3}$

\section{A B S T R A C T}

\section{Objective}

Study the prevalence of iron depletion and iron-deficiency anemia and their associated factors in preschool children.

\section{Methods}

Cross-sectional study with five-year old preschool children from a birth cohort of the city of Diamantina, Minas Gerais state, Brazil. Socioeconomic, demographic, and dietary characteristics were obtained through a questionnaire administered to each child mother or guardian. Iron depletion (normal hemoglobin and low serum ferritin levels) and iron-deficiency anemia (hemoglobin level than $11 \mathrm{~g} / \mathrm{dL}$ ) were detected after collecting $5 \mathrm{~mL}$ of venous blood of preschool children. Poisson regression was used to identify the factors associated with iron depletion and iron-deficiency anemia.

\footnotetext{
1 Universidade Federal dos Vales do Jequitinhonha e Mucuri, Faculdade de Ciências Biológicas e da Saúde, Departamento de Nutrição. Campus JK, Rod. MGT 367, km 583, 5000, Alto Jacuba, 39100-000, Diamantina, MG, Brasil. Correspondência paral Correspondence to: LN NOBRE. E-mail: <lunerinobre@yahoo.com.br>.

2 Universidade Federal de Minas Gerais, Faculdade de Medicina, Departamento de Pediatria. Belo Horizonte, MG, Brasil.

3 Universidade Federal de Viçosa, Centro de Ciências Biológicas II, Departamento de Nutrição. Viçosa, MG, Brasil. Support: Fundação de Amparo à Pesquisa do Estado de Minas Gerais (Process no APQ-00428-08).

Article based on the master's thesis of LN NOBRE, intitled "Fatores associados ao excesso de peso e de adiposidade e alteração no perfil lipídico de pré-escolares da cidade de Diamantina/MG". Universidade Federal de Minas Gerais; 2011.
} 


\section{Results}

A total of 228 preschool were evaluated, corresponding to $97.4 \%$ of the children from a cohort study followedup up to the end of their first year of life. Iron depletion and iron-deficiency anemia were detected, respectively, in $15.9 \%$ and $18.9 \%$ of the preschool children evaluated. Iron depletion was not associated with any variable studied, while low maternal education level was associated with iron-deficiency anemia ( $P R=1.83 ; P=0.03$ ).

\section{Conclusion}

Iron-deficiency anemia is considered as a mild public health problem among 5-year old children in the city of Diamantina, Minas Gerais. Higher maternal education level was a protective factor against this deficiency, and therefore it is as an important marker for the occurrence of iron-deficiency anemia in the population studied.

Keywords: Anemia, iron deficiency. Child, preschool. Educational status. Iron deficiency.

\section{R E S U M O}

\section{Objetivo}

Estudar a prevalência de depleção de ferro e anemia ferropriva em pré-escolares e conhecer seus fatores associados.

\section{Métodos}

Estudo transversal com pré-escolares com cinco anos de idade de uma coorte de nascimento do município de Diamantina, Minas Gerais. Características socioeconômicas, demográficas e dietéticas foram obtidas por meio de um questionário aplicado às mães ou responsáveis na residência de cada criança. A depleção de ferro (valores normais de hemoglobina e baixos de ferritina) e anemia ferropriva (hemoglobina inferior a 11 g/dL) foram identificadas após coleta de $5 \mathrm{~mL}$ de sangue venoso dos participantes. Regressão de Poisson foi utilizada para identificar os fatores associados à depleção de ferro e à anemia ferropriva.

\section{Resultados}

Foram avaliados 228 pré-escolares que corresponderam a 97,4\% das crianças acompanhadas até o final do primeiro ano do estudo de coorte. A depleção de ferro e a anemia ferropriva ocorreram, respectivamente, em 15,9\% e 18,9\% dos participantes avaliados. Depleção de ferro não se associou a nenhuma variável estudada, enquanto menor escolaridade materna associou-se com ocorrência de anemia ferropriva $(R P=1,83 ; P=0,03)$.

\section{Conclusão}

A anemia ferropriva se configura como um leve problema de saúde pública em crianças com cinco anos de idade em Diamantina. Maior escolaridade materna foi fator de proteção contra a carência, se configurando, portanto, como um importante marcador para a ocorrência da anemia ferropriva na população estudada.

Palavras-chave: Anemia ferropriva. Pré-escolar. Escolaridade. Deficiência de ferro.

\section{N T RO D U C T I O N}

Anemia is a global public health problem affecting both developing and developed countries with major consequences for human health as well as social and economic development [1].

This problem is the result of a wide variety of causes that can be isolated, but more often coexist. Iron-Deficiency Anemia (IDA) is the condition in which the hemoglobin concentration is abnormally low due to iron deficiency, which occurs when there is a long period of negative balance between the amount of biologically available iron and the need for this trace element. On the other hand, iron deficiency or iron depletion is characterized by the decreased iron stores, but the amount of functional iron is not affected. Thus, even though both are related to the same pathological condition, they are characterized by different degrees of deficiency [1].

The World Health Organization (WHO) [1] estimates that anemia has reached epidemic 
proportions, affecting 2 billion people worldwide. The Pesquisa Nacional de Demografia e Saúde da Criança e da Mulher [2] (National Demographic and Health Survey of Children and Women), conducted in 2006 , identified $20.9 \%$ prevalence of anemia in children under five years of age in the country in and $22.6 \%$ in the Southeastern region of the country. A recent publication of the WHO [3] on the global prevalence of anemia, considered the prevalence estimate for Brazil in 2011 as $24.0 \%$. In a population-based study of preschool children in Minas Gerais state, the estimate of anemia was 37.4\% [4]. Studies carried out in different cities in Brazil have shown prevalence among children $\geq 6$ years old ranging from $30.2 \%$ to $53.0 \%$ [5-9].

Preschool children are one of the most vulnerable population groups to develop this condition, causing concern due to its consequences such as impaired development and growth and increased levels of morbidity [1]. When it occurs in the early stages of child development, it can affect memory and cause cognitive impairment and learning disabilities [10].

The high incidence of childhood anemia has been associated with several factors: children aged $\leq 5$ years $[6,8,11,12]$, low family income $[5,8,13]$, high household density $[5,11-13]$, low maternal education level $[7,11,13,14]$, poor housing conditions, lack of adequate sanitation $[5,7,12]$, and some dietary variables such as low iron $[5,8,9,12]$ and protein [5] intake.

The prevalence of anemia remains high in Brazil despite the measures that have been adopted to prevent it such as food and nutrition education actions, flour fortification, and provision of iron supplements in the public health system for specific population groups. Therefore, this problem remains a major challenge to overcome. Moreover, no population-based study on this topic has been carried out with preschool children in the city of Diamantina, Minas Gerais, Brazil, which may hinder the development of prevention and control programs, as well as the assessment of their impact.
Considering these aspects, the present study aimed to investigate the prevalence of iron depletion and iron-deficiency anemia and their associated factors in preschool children in Diamantina (MG).

\section{METHODS}

This is a cross-sectional study nested within a birth cohort study carried out in Diamantina (MG) [15]. Characteristics of the cohort composition and the cross-sectional study, such as participants' age and variables investigated, were described in a previous study [16]. All children followed-up during their first year of life in the cohort study $(n=234)$ were eligible to participate in the present study. Of these 234 children, 228 were found and contacted; thus, the loss of the cohort participants of five years of age was $2.5 \%$.

The mothers of the children in that cohort study were contacted during the first weeks of the infant life in their own homes. Recruitment was based on the Declaration of Live Birth forms obtained from two local hospitals. The exclusion criteria to be included in the cohort were as follows: preterm infants, twins, infants born with malformations, and infants who did not live in the city of Diamantina (MG). The infants were follow-up at monthly intervals from birth to the first six months of life, and at three-month intervals from six to twelve months of life. During this follow-up period, weight and length measurements and information about infant feeding, introduction of complementary feeding, and other variables were obtained. The cohort study aimed to monitor the growth and development of infants during their first year of life [15].

Therefore, in the present study, data were collected through home visits to those children when they were 5 years \pm 4 months old. The children were subjected to socioeconomic status and dietary assessments, as well as biochemical and stool analysis. Socioeconomic and dietary 
data were evaluated during the home visits; the biochemical and stool analysis were scheduled so that the families could take their children to the Laboratory of Immunizations of the Nursing Department of the Universidade Federal dos Vales do Jequitinhonha e Mucuri (UFVJM). A staff member of the Clinical Analysis Laboratory was responsible for collecting the blood samples. The samples were transported by professionals in appropriate containers. Data collection occurred from July 2009 to July 2010 and was carried out by four nutritionists and one UFVJM Nutrition undergraduate student.

For the biochemical analysis, $5 \mathrm{~mL}$ venous blood samples were withdrawn from the children after 8-12 hours fasting. Blood tests were carried out by electronic counting; and hemoglobin was measured by absorbance using the cyanmethemoglobin hemoglobincyanide method, and serum ferritin was measured using the electro chemiluminescence method.

Children who had normal hemoglobin levels $(>11.0 \mathrm{~g} / \mathrm{dL}$ in children aged up to 59 months or $>11.5 \mathrm{~g} / \mathrm{dL}$ in children aged $>5$ years), and low serum ferritin levels $(<12 \mu \mathrm{g} / \mathrm{L}$ in children aged up to 59 months or $<15 \mathrm{~g} / \mathrm{L}$ in children aged $>5$ years) [1] were characterized as having "iron depletion". Those with low hemoglobin levels $(\leq 11.0 \mathrm{~g} / \mathrm{dL}$ in children aged up to 59 months or $\leq 11.5 \mathrm{~g} / \mathrm{dL}$ in children aged $>5$ years) [1] were classified as having "iron-deficiency anemia".

C-Reactive Protein (CRP) was also assessed in the present study using the immunoturbidimetric method. CRP value $>6 \mathrm{mg} / \mathrm{L}$ indicated infection or inflammatory process [17]. In these cases, iron depletion in children with high CRP levels $(>6 \mathrm{mg} / \mathrm{L}$ ) was diagnosed when the serum ferritin values were $<$ the $30 \mu \mathrm{g} / \mathrm{dL}[1]$.

For the stool test, fecal material was collected by parents and/or guardians using universal collectors. The families were instructed to bring the samples collected on the day of blood collection, which was previously scheduled and informed to the mother or guardian. Stool samples were examined for intestinal parasites using the method described by Hoffman and Baerman-Moraes, cited in WHO [18]. Nonpathogenic intestinal protozoa such as Entamoeba coli and Endolimax nana were not included in the analysis.

Dietary intake was assessed by three 24-Hour Dietary Recalls (24HR); two were administered on weekdays and one during the weekend [19]. Nutrient quantification was performed using the Dietpro software (A.S. Sistemas, Viçosa, Minas Gerais, Brazil) version $5 i$. The 24-hour recalls assessed iron, energy, and protein intake and dietary iron density. Dietary iron density was calculated by dividing the amount of iron intake per $100 \mathrm{kcal}$ of energy consumed [20]. After this step, the distribution of iron intake, iron dietary, and protein and energy intake were adjusted to reduce inter- and intraindividual variability using the Multiple Source Method (MSM) [21].

Estimated Energy Requirement (EER), energy required to maintain an energy balance consistent with good health [22], was also calculated. The physical activity factor used was 1.13 for girls and 1.16 for boys. The choice of low activity factors was due to the fact that children spend an average of 3 hours/day playing and only nine of them did some type of physical activity (e.g., swimming, soccer and ballet).

The independent variables were gender (male and female), per capita household income (in Minimum Wages [MW], $\leq 1 / 2 \mathrm{MW}$ and $>1 / 2$ $[\mathrm{MW}$ ], maternal education level [in years of schooling $[<9$ years and $\geq 9$ years]), presence of intestinal parasites (yes or no), and dietary variables: estimate of usual energy intake in tertiles (first tertile: $\leq 1304.2$; second tertile: >1304.2-1495.3; and hird tertile: >1495.3), estimate of usual protein intake in tertiles (first tertile: $\leq 48.7$; second tertile: $>48.7-57.6$; and third tertile: $\geq 57.9$ ), estimate of usual iron intake in tertiles (first tertile: $\leq 6.83$; second tertile: $>6.83-8.8$; and third tertile: $\geq 8.8$ ), and dietary iron density per $100 \mathrm{kcal}$ in tertiles (first tertile: $\leq 0.5$; second tertile: $>0.5-0.6$; and third tertile: $\geq 0.6$ ). 
The information mentioned was obtained through a semi-structured questionnaire administered to the children mothers or guardians and to the children's preschool/daycare center cooks. In the 24HRs administered on weekdays, the cooks assisted reporting the meals served and the serving sizes offered, expressed in household measures. The type and amount of food consumed by children with the habit of having a second helping were also identified. Given the difficulty in assessing dietary intake, it was considered that the portion size offered was consumed.

Under- and over-reporting of food intake is always a possibility; therefore, it was also assessed using the method proposed by Burrows et al. [23], in which the Energy Intake (EI) value was divided by the EER (EI/EER). El/EER ratio less than 0.84 indicates under-reporting; El/EER greater than 1.16 indicates over-reporting and EI/EER between 0.85 and 1.16 indicates accurate reporting.

Poisson regression was used to verify the association of anemia and iron depletion with the independent variables; binary Poisson regression for binary data was used in the model construction. The criterion used for the inclusion of variables in the multivariate model was a $p$-value $<0.20$. The selected variables were entered into the regression model one at a time, and those that did not remain significant were excluded. $P$-value $\leq 0.05$ was chosen as the significance level for the final model. Data were entered into an Excel spreadsheet and were analyzed using the Statistical Package for the Social Sciences (SPSS Inc., Chicago, Illinois, United States), version 19.0 for Windows.

The level of power in the sample was $98 \%$, and it was calculated using the prevalence of anemia and the risk associated with maternal education level obtained from the logistic regression as the parameters. Power analysis was carried out using the statistical software "G*Power" (Franz Faul, Universitat Kiel, Kiel, Germany) [24].
The present study was approved by the Ethics Committee for research on humans of the UFVJM (Protocol n 039/08). The research started after the parents or guardians signed an Informed Consent Form allowing their children to participate in the study.

\section{RES U L T S}

This study was carried out with 228 preschoolers out of the 234 children that were followed-up during their first year of life in the previously mentioned cohort study, accounting for $97.4 \%$ of those children. The participant losses were due to parental refusal to carry out the biochemical analysis, family moved away, and not locating the child's current address.

The average age of preschool children evaluated in this study was 5 years \pm 4 months. The prevalence of iron depletion was $15.9 \%$, and the prevalence of iron-deficiency anemia was $18.9 \%$. The average hemoglobin levels (boys and girls $=12.1 \mathrm{~g} / \mathrm{dL} ; P=0.82)$, serum ferritin (boys $=26.3$, girls $=25.7 \mu \mathrm{g} / \mathrm{L} ; P=0.12$ ), and $C R P$ (boys $=2.1 \%$, girls $=2.0 \mu \mathrm{g} / \mathrm{dL} ; P=0.20$ ) did not differ between the genders.

The distribution of preschoolers according to iron depletion and anemia and the socioeconomic and dietary variables is shown in Table 1. It can be seen that most children with iron depletion and iron-deficiency anemia had family earnings less than half the minimum wage (per capita), did not have parasites, were boys, and their mother had low education level.

Table 2 shows the results of the bivariate and adjusted analysis of the factors associated with iron depletion. It can be seen that there was a tendency for girls to be at lower risk for iron depletion (Prevalence Ratio - PR=0.57; $P=0.15$, Confidence Interval $-\mathrm{Cl}=0.26-1.22)$.

The results of the bivariate and adjusted analysis of the factors associated with irondeficiency anemia are shown in Table 3. It can be seen that in the bivariate analysis lower maternal 
Table 1. Prevalence of iron depletion and anemia in preschool children according to socioeconomic, health, and dietary variables. Diamantina (MG), Brazil (2010).

\begin{tabular}{|c|c|c|c|c|c|c|c|c|c|c|}
\hline \multirow{3}{*}{ Variables } & \multicolumn{5}{|c|}{ Iron depletion } & \multicolumn{5}{|c|}{ Iron-deficiency anemia } \\
\hline & \multicolumn{2}{|c|}{ No $(n=192)$} & \multicolumn{2}{|c|}{ Yes $(n=36)$} & \multirow{2}{*}{$p$-value } & \multicolumn{2}{|c|}{ No $(n=185)$} & \multicolumn{2}{|c|}{ Yes $(n=43)$} & \multirow{2}{*}{$p$-value } \\
\hline & $\mathrm{n}$ & $\%$ & $\mathrm{n}$ & $\%$ & & $\mathrm{n}$ & $\%$ & $\mathrm{n}$ & $\%$ & \\
\hline \multicolumn{11}{|c|}{ Per capita household income ${ }^{1}$} \\
\hline$\geq 1 / 2 M W(n=90)$ & 77 & 40.1 & 13 & 36.1 & \multirow{2}{*}{0.65} & 77 & 41.8 & 13 & 30.2 & \multirow{2}{*}{0.16} \\
\hline$<1 / 2 \mathrm{MW}(\mathrm{n}=138)$ & 115 & 59.8 & 23 & 63.9 & & 108 & 58.2 & 30 & 69.7 & \\
\hline \multicolumn{11}{|c|}{ Presence of intestinal parasites } \\
\hline Yes $(n=71)$ & 60 & 33.5 & 11 & 30.4 & \multirow{2}{*}{0.98} & 58 & 33.9 & 13 & 31.7 & \multirow{2}{*}{0.78} \\
\hline No $(n=141)$ & 119 & 66.4 & 22 & 61.1 & & 113 & 66.0 & 28 & 68.2 & \\
\hline \multicolumn{11}{|c|}{ Maternal education level (years) } \\
\hline$\geq 9(n=114)$ & 97 & 50.5 & 17 & 47.2 & \multirow{2}{*}{0.71} & 99 & 53.5 & 15 & 34.8 & \multirow{2}{*}{0.02} \\
\hline$<9(n=113)$ & 95 & 49.4 & 19 & 52.8 & & 86 & 46.4 & 28 & 65.1 & \\
\hline \multicolumn{11}{|l|}{ Gender } \\
\hline Female $(n=86)$ & 86 & 40.1 & 9 & 25.0 & \multirow{2}{*}{0.08} & 69 & 37.2 & 17 & 39.5 & \multirow{2}{*}{0.78} \\
\hline Male $(n=142)$ & 142 & 59.8 & 27 & 75.0 & & 116 & 62.7 & 26 & 60.4 & \\
\hline \multicolumn{11}{|l|}{ Iron intake (mg/day) ${ }^{2}$} \\
\hline$\leq 7.1(n=71)$ & 62 & 32.3 & 9 & 25.0 & \multirow{3}{*}{0.27} & 55 & 29.7 & 11 & 25.5 & \multirow{3}{*}{0.14} \\
\hline$>7.1 \leq 8.6(n=78)$ & 66 & 34.3 & 12 & 33.3 & & 62 & 33.5 & 16 & 37.2 & \\
\hline$\leq 8.6(n=79)$ & 64 & 33.3 & 15 & 41.6 & & 68 & 36.7 & 16 & 37.2 & \\
\hline \multicolumn{11}{|c|}{ Dietary Iron density (g/100kcal)³ } \\
\hline$\leq 0.5(n=40)$ & 37 & 19.3 & 3 & 8.33 & \multirow{3}{*}{0.28} & 32 & 17.2 & 8 & 18.6 & \multirow{3}{*}{0.21} \\
\hline$>0.4 \leq 0.6(n=98)$ & 80 & 41.6 & 18 & 50.0 & & 78 & 42.1 & 20 & 46.4 & \\
\hline$>0.6(n=90)$ & 75 & 39.1 & 15 & 41.6 & & 75 & 40.5 & 15 & 34.9 & \\
\hline \multicolumn{11}{|l|}{ Protein intake (g/day) ${ }^{4}$} \\
\hline$\leq 48.7(n=74)$ & 65 & 33.8 & 9 & 25.0 & & 55 & 29.7 & 19 & 44.1 & \\
\hline$>48.7 \leq 57.9(n=79)$ & 63 & 32.8 & 16 & 44.5 & 0.68 & 65 & 35.1 & 12 & 27.9 & 0.14 \\
\hline$>57.9(n=75)$ & 64 & 33.3 & 11 & 30.4 & & 65 & 35.1 & 10 & 23.2 & \\
\hline Energy intake (kcal/day) 5 & & & & & & & & & & \\
\hline$\leq 1304.2(n=78)$ & 69 & 34.3 & 9 & 25.0 & & 56 & 30.2 & 19 & 44.1 & \\
\hline$>1304.2 \leq 1495.3(n=77)$ & 62 & 32.3 & 15 & 41.6 & 0.52 & 65 & 35.1 & 12 & 27.9 & 0.21 \\
\hline$>1495.3(n=76)$ & 64 & 33.3 & 12 & 33.3 & & 64 & 34.5 & 12 & 27.9 & \\
\hline
\end{tabular}

${ }^{1}$ Value refers to 1 minimum wage $-\mathrm{R} \$ 540,00 .{ }^{2}$ Value refers to the estimate of usual iron intake in tertiles. ${ }^{3}$ Value refers to the estimate of usual per $100 \mathrm{kcal}$ in tertiles. ${ }^{4}$ Value refers to the estimate of usual protein intake in tertiles. ${ }^{5}$ Value refers to the estimate of usual energy intake in tertiles. Usual intake estimate was assessed using the Multiple Source Method (MSM).

education level was associated with anemia ( $P R=1.86 ; P=0.03)$ and that per capita household income, estimate of usual intake of iron, protein, and energy had a $p$-value $<0.20$. In the adjusted analysis, all of these variables were entered into the model; however, low maternal education level was the only variable that remained associated with the occurrence of anemia ( $P R=1.83 ; p=0.03$, $\mathrm{Cl}=1.03-3.24)$.

As for the assessment of the estimate of nutrient intake, under-reporting occurred in $22.0 \%(n=50)$ of the preschool children evaluated; over-reporting in $21.5 \%(n=55.8)$, and accurate reporting in $56.5 \%(n=129)$.

\section{DISCUSSION}

In the present study, the prevalence of iron depletion and iron-deficiency anemia in five-year old children of a cohort in the city of Diamantina (MG), were investigated. It is important to mention that most studies on this topic in Brazil have investigated iron-deficiency anemia $[2,5,7,8,12,25-29]$, and few have evaluated these 
Table 2. Crude and adjusted prevalence ratio of the analysis of the variables associated with iron depletion in preschool children. Diamantina (MG), Brazil (2010).

\begin{tabular}{|c|c|c|c|c|c|c|}
\hline \multirow{2}{*}{ Variables } & \multicolumn{6}{|c|}{ Iron depletion } \\
\hline & Crude PR & $p$-value & $95 \% \mathrm{Cl}$ & Adjusted PR & $p$-value & $95 \% \mathrm{Cl}$ \\
\hline \multicolumn{7}{|c|}{ Per capita household income ${ }^{1}$} \\
\hline$\geq 1 / 2 \mathrm{MW}$ & 1 & & & & & \\
\hline$<1 / 2 \mathrm{MW}$ & 1.15 & 0.68 & $0.58-2.27$ & & & \\
\hline \multicolumn{7}{|c|}{ Presence of intestinal parasites } \\
\hline No & 1 & & & & & \\
\hline Yes & 0.99 & 0.98 & $0.48-2.04$ & & & \\
\hline \multicolumn{7}{|c|}{ Maternal education level (years) } \\
\hline$\geq 9$ & 1 & & & & & \\
\hline$<9$ & 1.11 & 0.73 & $0.58-2.15$ & & & \\
\hline \multicolumn{7}{|l|}{ Gender } \\
\hline Male & 1 & & & 1 & & \\
\hline Female & 0.55 & 0.12 & $0.25-1.17$ & 0.57 & 0.15 & $0.26-1.22$ \\
\hline \multicolumn{7}{|c|}{ Iron intake $(m g / d a y)^{2}$} \\
\hline$\leq 7.1$ & 0.66 & 0.33 & $0.29-1.52$ & & & \\
\hline$>7.1 \leq 8.6$ & 0.81 & 0.58 & $0.37-1.73$ & & & \\
\hline$\leq 8.6$ & 1 & & & & & \\
\hline \multicolumn{7}{|c|}{ Dietary Iron density (g/100kcal)³ } \\
\hline$\leq 0.5$ & 0.45 & 0.20 & $0.13-1.55$ & 0.48 & 0.24 & $0.29-1.22$ \\
\hline$>0.4 \leq 0.6$ & 1.10 & 0.78 & $0.55-2.18$ & 1.15 & 0.75 & $0.56-2.20$ \\
\hline$>0.6$ & 1 & & & 1 & & \\
\hline \multicolumn{7}{|c|}{ Protein intake $(g / \text { day })^{4}$} \\
\hline$\leq 48.7$ & 0.82 & 0.67 & $0.34-2.00$ & & & \\
\hline$>48.7 \leq 57.9$ & 1.38 & 0.41 & $0.64-2.97$ & & & \\
\hline$>57.9$ & 1 & & & & & \\
\hline \multicolumn{7}{|c|}{ Energy intake (kcal/day) ${ }^{5}$} \\
\hline$\leq 1304.2$ & 0.76 & 0.53 & $0.32-1.80$ & & & \\
\hline$>1304.2 \leq 1495.3$ & 1.23 & 0.58 & $0.57-2.63$ & & & \\
\hline$>1495.3$ & 1 & & & & & \\
\hline
\end{tabular}

${ }^{1}$ Value refers to 1 minimum wage - $R \$ 540,00 .{ }^{2}$ Value refers to the estimate of usual iron intake in tertiles. ${ }^{3}$ Value refers to the estimate of usual per $100 \mathrm{kcal}$ in tertiles. ${ }^{4}$ Value refers to the estimate of usual protein intake in tertiles. ${ }^{5}$ Value refers to the estimate of usual energy intake in tertiles. Usual intake estimate was assessed using the Multiple Source Method (MSM).

PR: Prevalence Ratio; 95\%Cl: 95\% Confidence Interval.

two conditions $[6,30,31]$. Therefore, our data will, in most cases, be compared with studies that investigated iron-deficiency anemia.

In the present study, the prevalence of iron depletion $(15.9 \%)$ was similar to that of irondeficiency anemia (18.94\%). This result differs from those of studies that also investigated these two conditions [6,30,31]. Castro et al. [6] assessed the factors associated with iron deficiency and iron-deficiency anemia in children aged 6-60 months in an urban area of two municipalities in the state of Acre and identified prevalence of
$43.5 \%$ of iron depletion, which is more than twice the value found for anemia (20.9\%). Carvalho et al. [30] investigated 6-30 month old children who attended public daycare centers in Recife, Pernambuco, Brazil and found that the prevalence of iron-deficiency anemia (58.1\%) was much higher than that of iron depletion (2.3\%). Rezende et al. [31] studied school children aged 7-15 years in Novo Cruzeiro, a city located in the same region evaluated in the present study, Vale do Jequitinhonha, and found prevalence of anemia of $12.1 \%$ and iron depletion of $26.7 \%$. 
Table 3. Crude and adjusted prevalence ratio of the analysis of the variables associated with iron-deficiency anemia in preschool children. Diamantina (MG), Brazil (2010).

\begin{tabular}{|c|c|c|c|c|c|c|}
\hline \multirow{2}{*}{ Variables } & \multicolumn{6}{|c|}{ Iron-deficiency anemia } \\
\hline & Crude PR & $p$-value & $95 \% \mathrm{Cl}$ & Adjusted PR & $p$-value & $95 \% \mathrm{Cl}$ \\
\hline \multicolumn{7}{|c|}{ Per capita household income ${ }^{1}$} \\
\hline$\geq 1 / 2 \mathrm{MW}$ & 1 & & & & & \\
\hline$<1 / 2 \mathrm{MW}$ & 1.50 & 0.17 & $0.83-2.72$ & & & \\
\hline \multicolumn{7}{|c|}{ Presence of intestinal parasites } \\
\hline No & 1 & & & & & \\
\hline Yes & 0.92 & 0.78 & $0.51-1.66$ & & & \\
\hline \multicolumn{7}{|c|}{ Maternal education level (years) } \\
\hline$\geq 9$ & 1 & & & 1 & & \\
\hline$<9$ & 1.86 & 0.03 & $1.05-3.30$ & 1.83 & 0.03 & $1.03-3.24$ \\
\hline \multicolumn{7}{|l|}{ Gender } \\
\hline Female & 1 & & & & & \\
\hline Male & 1.08 & 0.78 & $0.62-1.87$ & & & \\
\hline \multicolumn{7}{|c|}{ Iron intake $(m g / d a y)^{2}$} \\
\hline$\leq 7.1$ & 1.61 & 0.17 & $0.80-3.25$ & 1.53 & 0.22 & $0.76-3.06$ \\
\hline$>7.1 \leq 8.6$ & 1.47 & 0.27 & $0.73-2.97$ & 1.46 & 0.27 & $0.59-2.94$ \\
\hline$\leq 8.6$ & 1 & & & 1 & & \\
\hline \multicolumn{7}{|c|}{ Dietary Iron density (g/100kcal)3 } \\
\hline$\leq 0.5$ & 1.20 & 0.64 & $0.55-2.66$ & & & \\
\hline$>0.4 \leq 0.6$ & 1.22 & 0.51 & $0.66-2.24$ & & & \\
\hline$>0.6$ & 1 & & & & & \\
\hline \multicolumn{7}{|c|}{ Protein intake (g/day) $)^{4}$} \\
\hline$\leq 48.7$ & 1.92 & 0.06 & $0.96-3.85$ & & & \\
\hline$>48.7 \leq 57.9$ & 1.32 & 0.45 & $0.62-2.80$ & & & \\
\hline$>57.9$ & 1 & & & & & \\
\hline \multicolumn{7}{|c|}{ Energy intake (kcal/day) ${ }^{5}$} \\
\hline$\leq 1304.2$ & 1.60 & 0.15 & $0.83-3.06$ & & & \\
\hline$>1304.2 \leq 1495.3$ & 0.98 & 0.97 & $0.47-2.05$ & & & \\
\hline$>1495.3$ & 1 & & & & & \\
\hline
\end{tabular}

${ }^{1}$ Value refers to 1 minimum wage - $R \$ 540,00 .{ }^{2}$ Value refers to the estimate of usual iron intake in tertiles. ${ }^{3}$ Value refers to the estimate of usual per $100 \mathrm{kcal}$ in tertiles. ${ }^{4}$ Value refers to the estimate of usual protein intake in tertiles. ${ }^{5}$ Value refers to the estimate of usual energy intake in tertiles. Usual intake estimate was assessed using the Multiple Source Method (MSM).

PR: Prevalence Ratio; 95\%Cl: 95\% Confidence Interval.

According to $\mathrm{WHO}$ [32], it is expected that the prevalence of iron depletion exceeds that of anemia since this can be considered an initial stage of anemia; however, our findings were a little different. The low prevalence of iron depletion found can be justified by the methodological rigor of the present study since we assessed the CRP to prevent classifying children who had an infection as healthy. In these cases, serum ferritin levels may increase 2-4 times [1]. Moreover, since the present study was nested within a birth cohort study, there was no difference in age range such as that in the studies cited in this article. In the present study, 5 year old children were evaluated, and at this the age children are less susceptible to this type of deficiency than children under two years old. Moreover, the projection made in $\mathrm{WHO}$ [32] deserves revision, especially in terms of the validity of this projection in different scenarios.

It is worth mentioning that iron deficiency has different degrees, ranging from iron depletion, which causes no physiological impairments, to iron-deficiency anemia, which affects the functioning of several organ systems. Iron 
depletion refers to the reduction in the amount of stored iron, but the amount of functional iron may not be affected. In other words, individuals who have iron depletion have no iron stores to mobilize if the body requires more iron. Therefore, although according to $\mathrm{WHO}$ [3] prevalence of anemia from 5 to $19.9 \%$ is considered a mild public health problem, in this study, it was found a significant number of children that are at risk of developing iron-deficiency anemia if no action is taken since they have no iron stores.

With regard to the factors associated with iron depletion, none of the variables studied was significantly associated with this condition. However, girls tended to be more protected against iron depletion, corroborating the findings of another study that showed increased risk of anemia and iron deficiency among boys [6]. This can be explained in part by genetic differences, i.e., the growth rate for boys is higher, which results in greater need for iron that cannot be provided by the diet [33].

The prevalence of iron-deficiency anemia in pre-school children found in this study was similar to that reported in another national study (20.9\%) [2] and lower than that found in two other studies carried out in different Brazilian cities $[5,7,25,26]$, which reported prevalence ranging from $30.2 \%$ to $68.8 \%$. Studies carried out in Grece [11], China [13], and Haiti [34] identified prevalence of iron-deficiency anemia ranging from $35.12 \%$ to $38.8 \%$.

A possible explanation for the prevalence of anemia found in the present study is that Diamantina is located in the Vale do Jequitinhonha, an area where Vitamin A deficiency is endemic and vitamin A supplementation is regularly provided to children $\leq 5$ years old. Therefore, such supplementation may have acted as a protective factor against iron-deficiency anemia in the children assessed. Approximately $99 \%$ of those children received supplementation; only three children were not given vitamin $A$ supplements since they did not live in the Vale do Jequitinhonha at the time of data collection.
As for the factors associated with irondeficiency anemia, the only variable that was significantly associated with this disorder in the present study was low maternal education level. This result is similar to those found by other researchers $[7,11,13,14,27]$. Oliveira et al. [27] assessed the prevalence of anemia and its associated factors in children 6-59 months in the state of Pernambuco and found that the children whose mothers had less than 4 years of schooling were more than twice as likely to be anemic. Tympa-Psirropoulou et al. [11] investigated the prevalence of anemia in children aged 12-24 months in Greece and found that parents' education affected the presence of anemia in children; the number of cases of anemia was higher among children whose parents had only primary or secondary education. Yang et al. [13] studied children aged 0-18 months in the Shaanxi Province in Northwestern China and also found that low maternal education was associated with the presence of anemia among the children evaluated.

One possible explanation for these results is that higher maternal education level can lead to better health knowledge, more rational decisions about the use of family income, and better job opportunities and earnings, which can lead to the provision of better health care to their children and promotion of healthier dietary habits [14].

Although the variables iron intake and dietary iron density were not associated with anemia in the present study, adequate intake of this mineral is very important to prevent anemia [8]. The low consumption of foods that are source of bioavailable iron, such as meat, can lead to an increase in the development of this condition. Furthermore, it is known that higher income households have greater access to food, especially meat. However, although the family earnings of approximately $60.0 \%$ of the children in this study was half the minimum wage (per capita) and the prevalence of anemia among them was high $(21.7 \%)$, household income was not identified 
as a risk factor for this problem in the sample studied. This result is in agreement with the Pesquisa Nacional de Demografia Saúde (PNDS-2006 [2]) (National Demographic and Health Survey of Children and Women) results for children aged 6-59 months, in which there were statistically different prevalence rates of anemia in various economic strata.

According to Oliveira et al. [27], inadequate dietary practices are the main risk factors for developing anemia. Higher dietary iron intake, together with an enhancer of nonheme iron absorption (vitamin C and meat, for example), has been associated with the absence of anemia in children.

It is important to emphasize that in Brazil anemia persists as a public health problem that needs to be solved. This can be confirmed by the results found in the present study and the results of other studies discussed here. Although Brazil has adopted a program to combat iron-deficiency anemia for over 10 years - flour fortification - it appears that some children in this study are not benefiting from it or this measure may not have been effective.

This study have some limitations, and the most important is related to the assessment of children's dietary habits since most mothers $(62.5 \%)$ work outside the home and most children (88.79\%) attend schools on a regular basis. This made it difficult to obtain accurate information about food consumption. To minimize this problem, three $24-\mathrm{HR}$ dietary recall interviews were conducted (two during the week and one on the weekend) and all schools were visited to investigate food preparations and serving sizes offered. However, it is difficult to ensure that all food provided was consumed by the children, which is a challenge inherent in most studies that involve children that attend school on a regular basis. Nevertheless, the dietary data obtained in this study can be considered valid since the prevalence of under-reporting of energy intake $(22.03 \%)$ was very similar to that of the overreporting of energy intake $(21.58 \%)$. Thus, according to the method proposed by Burrows et al. [23], our data can be characterized as not biased.

\section{CONCLUSION}

Although the prevalence of anemia in the preschool children evaluated in the present study is considered by WHO as a mild public health problem, it cannot be neglected due to its consequences for child development. The protection against iron-deficiency anemia due to better maternal education level may indicate more rational decisions about the use of family income, better chances of obtaining and retaining information about the prevention of this nutritional deficiency, and consequently the provision of better health care to their children and promotion of healthy dietary habits. Therefore, the following actions should be carried out: short-term actions so that health care centers can provide more appropriate care to help and educate mothers and long-term actions to improve women's education level.

\section{CONTRIBUTORS}

The authors HC OLIVEIRA, AC LESSA, and JA LAMOUNIER contributed to data analysis, and the authors LN NOBRE and SCC FRANCISCHINI contributed to study conception and design, and data analysis and interpretation. The article is based on a master's thesis.

\section{REFERE N CES}

1. World Health Organization. Worldwide prevalence of anaemia 1993-2005: WHO global database on anaemia. Geneva: WHO; 2008.

2. Ministério da Saúde. Pesquisa Nacional de Demografia e Saúde da Criança e da Mulher - PNDS/ 2006. Brasília: Ministério da Saúde; 2008.

3. World Health Organization. The global prevalence of anemia in 2011. Geneva: WHO; 2015.

4. Lisbôa MBMC, Oliveira EO, Lamounier JAS, Mariano CA, Freitas RN. Prevalence of iron-deficiency 
anemia in children aged less than 60 months: A population-based study from the state of Minas Gerais, Brazil. Rev Nutr. 2015;28(2):121-31. https:// doi.org/10.1590/1415-52732015000200001

5. Assis AMO, Barreto ML, Gomes GSS, Prado MS, Santos NJ, Santos LMP, et al. Childhood anemia prevalence and associated factors in Salvador, Bahia, Brazil. Cad Saúde Pública. 2004;20(6):1633-41. https://doi.org/10.1590/S0102-311X200400060 0022

6. Castro TG, Silva-Nunes M, Conde WL, Muniz PT, Cardoso MA. Anemia e deficiência de ferro em pré-escolares da Amazônia Ocidental brasileira: prevalência e fatores associados. Cad Saúde Pública. 2011;27(1):131-42. https://doi.org/10.1590/S0 102-311X2011000100014

7. Oliveira MAA, Osório MM, Raposo MCF. Socioeconomic and dietary risk factors for anemia in children aged 6 to 59 months. J Pediatr. 2007;83(1):39-46. https://doi.org/10.2223/JPED. 1579

8. Vitolo MR, Bortolini GA. Biodisponibilidade do ferro como fator de proteção contra anemia entre crianças de 12 a 16 meses. J Pediatr. 2007;83(1):33-8. https://doi.org/10.2223/JPED.1577

9. Zuffo CRK, Osório MM, Taconeli CAS, Schmidt T, Silva BHC da C, Almeida CB. Prevalência e fatores de risco da anemia em crianças. J Pediatr; 2016;92(4):353-60. https://doi.org/10.1016/j. jpedp.2016.02.008

10. Fretham SJ, Carlson ES, Georgieff MK. The role of iron in learning and memory. Adv Nutr. 2011;2(2):112-21.https://doi.org10.3945/an. 110.000190

11. Tympa-Psirropoulou E, Vagenas C, Dafni O, Matala A, Skopouli F. Environmental risk factors for iron deficiency old in the area of Thessalia in Greece. Hippokratia. 2008;12(4):240-50.

12. Vieira RCS, Ferreira HS, Costa ACS, Moura FA, Florêncio TMMT, Torres ZMC. Prevalência e fatores de risco para anemia em crianças pré-escolares do Estado de Alagoas, Brasil. Rev Bras Saúde Mater Infant. 2010;10(1):107-16. https://doi.org/10. 1590/S1519-38292010000100011

13. Yang W, Li X, Li Y, Zhang S, Liu L, Wang $X$, et al. Anemia, malnutrition and their correlations with socio-demographic characteristics and feeding practices among infants aged 0-18 months in rural areas of Shaanxi province in northwestern China: A cross-sectional study. BMC Public Health. 2012;12(1):1127-34. https://doi:10.1186/1471-24 58-12-1127

14. Osório MM. Fatores determinantes da anemia em crianças. J Pediatr. 2002;78(4):269-78. https:// doi.org/10.1590/S0021-75572002000400005
15. Lessa AC. Alimentação e crescimento no primeiro ano de vida: um estudo de coorte [tese]. Salvador: Universidade Federal da Bahia; 2010.

16. Nobre LN, Lamounier JA, Franceschini SCC. Padrão alimentar de pré-escolares e fatores associados. J Pediatr. 2012;88(2):129-36. https://doi.org/10.22 23/JPED.2169

17. Kushner I. Regulation of the acute phase response by cytokines. Perspect Biol Med. 1993;36(4):611-22. https://doi.org/10.1353/pbm.1993.0004

18. World Health Organization. Basic laboratory methods in medical parasitology. Geneva: WHO; 1991.

19. Willet WC. Nutritional epidemiology. New York: Oxford University Press; 1998.

20. Hallberg L. Bioavailable nutrient density: A new concept applied in the interpretation of food iron absorption data. Am J Clin Nutr. 1981;34(10):2242-7.

21. Harttig U, Haubrock J, Knuppel S, Boeing $H$, Consortium EFCOVAL. The MSM program: Web-based statistics package for estimating usual dietary intake using the Multiple Source Method. Eur J Clin Nutr. 2011;65(Suppl.1);S87-S91. https://doi.org/10. 1038/ejcn.2011.92

22. National Research Council. Dietary reference intakes for energy, carbohydrate, fiber, fat, fatty acids, cholesterol, protein, and amino acids (macronutrients). Washington (DC): National Academy Press; 2002.

23. Burrows TL, Martin RJ, Collins CE. A systematic review of the validity of dietary assessment methods in children when compared with the method of doubly labeled water. J Am Diet Assoc. 2010;110(10):1501-10. https://doi.org/10.1016/j. jada.2010.07.008

24. Portney LG, Watkins, MP. Foundations of Clinical Research: Applications to Practice. 3rd ed. New Jersey: Prentice Hall; 2008.

25. Cotta RMM, Oliveira FCC, Magalhães KA, Ribeiro AQ, Sant'Ana LFR, Priore SE, et al. Social and biological determinants of iron deficiency anemia. Cad Saúde Pública. 2011;27(2):s309-20. https:// doi.org/10.1590/S0102-311X2011001400017

26. Gondim SSR, Diniz AS, Cagliari MPP, Araújo ES, Queiroz D, Paiva AA. Relação entre níveis de hemoglobina, concentração de retinol sérico e estado nutricional em crianças de 6 a 59 meses do Estado da Paraíba. Rev Nutr. 2012;25(4):441-9. https://doi.org/10.1590/S1415-527320120004 00002

27. Oliveira CSM, Cardoso MA, Araújo TS, Muniz PT. Anemia em crianças de 6 a 59 meses e fatores associados no Município de Jordão, Estado do Acre, Brasil. Cad Saúde Pública. 2011;27(5):1008-20. 
https://doi.org/10.1590/S0102-311X20110005 00018

28. Oliveira TSC, Silva MC, Santos JN, Rocha DS, Alves $\mathrm{CRL}$, Capanema FD, et al. Anemia entre préescolares: um problema de saúde pública em Belo Horizonte, Brasil. Ciênc Saúde Coletiva. 2014;19(1):59-66. https://doi.org/10.1590/1413-8 1232014191.1927

29. Lisboa MBMC, Oliveira EO, Lamounier JA, Silva CAM, Freitas RN. Prevalence of iron-deficiency anemia in children aged less than 60 months: A population-based study from the state of Minas Gerais, Brazil. Rev Nutr. 2015;28(2):121-31. https:// doi.org/10.1590/1415-52732015000200001

30. Carvalho AGC, Lira PIC, Barros MFA, Aléssio MLM, Lima MC, Carbonneau MA, et al. Diagnosis of iron deficiency anemia in children of Northeast Brazil. Rev Saúde Pública. 2010;44(3):513-9. https://doi. org/10.1590/S0034-89102010000300015

31. Rezende EG, Santos MA, Lamounier JA, Galvão MAM, Leite RC. Deficiência de ferro e anemia em escolares da área rural de Novo Cruzeiro (Minas Gerais) Brasil. Rev Med Minas Gerais. 2009;19(2):103-8.

32. World Health Organization. Iron deficiency anaemia: Assessment, prevention and control. A guide for programme managers. Geneva: WHO; 2001.

33. Domellof M, Lonnerdal B, Dewey KG, Cohen RJ, Rivera LL, Hernell O. Sex differences in iron status during infancy. Pediatrics. 2002;110:545-52.

34. Ayoya MA, Ngnie-Teta I, Séraphin MN, Mamadoultaibou A, Boldon E, Saint-Fleur JE, et al. Prevalence and risk factors of anemia among children 6-59 months old in Haiti. Anemia. 2013;2013:502968. https://doi.org/10.1155/2013/ 502968

Received: December 15, 2015 Final version: October 19, 2016 Approved: November 11, 2016 